\title{
Soft Tissue Sarcoma of the Head and Neck cM0 TNM Finding v8
}

National Cancer Institute

\section{Source}

National Cancer Institute. Soft Tissue Sarcoma of the Head and Neck cMO TNM Finding v8. NCI Thesaurus. Code C136658.

Soft tissue sarcoma of the head and neck without distant metastasis. (from AJCC 8th Ed.) 